\title{
Link between metformin and the peroxisome proliferator-activated receptor $\gamma$ pathway in the uterine tissue of hyperandrogenized prepubertal mice
}

\begin{abstract}
Chronic hyperandrogenism alters the peroxisome proliferator-activated receptor $\gamma$ (PPAR $\gamma$ ) pathway in the uterine tissue of prepubertal mice. The gene and protein expression of PPAR $\gamma$ is not modified, but the gene and protein expression of 12-lipoxygenase (12-LOX), an enzyme that synthesizes PPAR $\gamma$ ligands, is decreased. The antihyperglycemic drug metformin can prevent this adverse effect. (Fertil Steril ${ }^{\circledR} 2011 ; 95: 2534-7$. (C2011 by American Society for Reproductive Medicine.)
\end{abstract}

Key Words: Lipoxygenases, metformin, peroxisome proliferator activated receptor gamma, polycystic ovary syndrome, uterus

Polycystic ovary syndrome (PCOS) is a disease characterized by hyperandrogenism, hirsutism, oligomenorrhea or amenorrhea, and anovulation (1). The excess of androgens has a detrimental effect on endometrial function, which can lead to infertility (2-4) and even endometrial cancer (5-8). By the use of a hyperandrogenized murine model, we previously found that the excess of androgens induced embryo resorption of early pregnant mice (9-11) and promoted the development of uterine structures that were closely related to precancerous structures $(7,8)$.

$N, N^{\prime}$-dimethylbiguanide metformin is one of the most common drugs used for the treatment of type 2 diabetes. Metformin activates

\section{Evelin M. Elia ${ }^{\mathrm{a}}$}

Carolina Pustovrh, Ph.D. ${ }^{\text {b,c }}$

Sabrina Amalfi ${ }^{\mathrm{a}}$

Luigi Devoto, Ph.D. ${ }^{\mathrm{c}}$

Alicia Beatriz Motta, Ph.D. ${ }^{\text {a }}$

${ }^{a}$ Centro de Estudios Farmacológicos y Botánicos (CEFYBO), Consejo Nacional de Investigaciones Científicas y Tecnológicas (CONICET), Buenos Aires, Argentina

${ }^{b}$ Instituto de Fisiología, Biología Molecular y Neurociencia (IFIBYNE), Facultad de Ciencias Exactas y Naturales, Universidad de Buenos Aires, Buenos Aires, Argentina

${ }^{c}$ Instituto de Investigaciones Materno Infantil, Hospital Clínico San Borja-Arriarán, Facultad de Medicina, Universidad de Chile, Santiago, Chile

Received November 9, 2010; revised and accepted February 2, 2011; published online March 5, 2011.

E.M.E. has nothing to disclose. C.P. has nothing to disclose. S.A. has nothing to disclose. L.D. has nothing to disclose. A.B.M. has nothing to disclose. Supported by the Agencia Nacional de Promoción Científica y Tecnológica (grants PICTR 32529/05 and PICT 949/06), the Consejo Nacional de Investigación Científica y Técnica (grant 185), the Fundación Alberto Roemmers, and the Programa Latinoamericano de Investigación en Salud Sexual y Reproductiva (PLISSER).

Reprint requests: Alicia Beatriz Motta, Ph.D., CEFYBO, CONICET, Paraguay 2155, Buenos Aires, Argentina. (E-mail: aliciabmotta@ yahoo.com.ar). the adenosine $3^{\prime}: 5^{\prime}$ monophosphate (AMP)-dependent kinase $\alpha$ (AMPK- $\alpha)$ pathway to decrease glucose production, increase fatty acid oxidation, and promote the uptake of glucose by cells (12-14). In PCOS patients, metformin decreases androgen levels, improves the frequency of ovulation and menstrual cycles (15-18), and prevents abortions $(17,19,20)$. However, little is known about the mechanisms by which metformin restores uterine functions in women with PCOS. In this context, we previously reported elsewhere that metformin prevents the adverse effects induced by hyperandrogenism in uterine tissue, including the appearance of abnormal endometrial structure (8).

Peroxisome proliferator-activated receptors (PPARs) are a family of transcriptional nuclear factors with three isoforms, $\alpha, \beta$, and $\gamma$, which regulate the expression of multiple genes (21). Lipoxygenase (LOX) metabolizes arachidonic and linoleic acids, producing eicosanoids $(22,23)$. The primary metabolites of arachidonic acid generated by 1-LOX are the leukotrienes and lipoxines, whereas those produced by 12 -LOX and 15-LOX are hydroxyeicosatetraenoic acids (HETEs) $(24,25)$. It is known that the uterine PPAR $\gamma$ pathway regulates implantation in mice by modulating the $12 / 15$ LOX system (26). These findings, together with the fact that metformin and the PPAR system have been related in a synergistic action $(27,28)$, led us to study the expression of PPAR $\gamma, 12-\mathrm{LOX}$, and 15-LOX in uterine tissue from hyperandrogenized mice and their relationship with the metformin treatment.

The animal model (7-11) consisted of female prepubertal (25-dayold) mice of the BALB/c strain. The dehydroepiandrosterone (DHEA) group consisted of animals injected daily with DHEA $(6 \mathrm{mg} / 100 \mathrm{~g}$ body weight, dissolved in $0.10 \mathrm{~mL}$ sesame oil) for 20 consecutive days, and the DHEA + M group consisted of animals injected with DHEA and given metformin orally $(50 \mathrm{mg} / 100 \mathrm{~g}$ body weight in $0.05 \mathrm{~mL}$ of water, given orally with a cannula) for 20 days. The controls consisted of two groups: [1] animals injected with oil (0.1 $\mathrm{mL})$ and given water orally $(0.05 \mathrm{~mL})$ for 20 consecutive days $(\mathrm{C}$ group) and [2] the metformin-alone group which consisted of mice treated orally with $50 \mathrm{mg}$ metformin/ $\mathrm{kg}$ body weight in $0.05 \mathrm{~mL}$ of water for 20 days (M group). Mice (10 per group) were housed under 
controlled temperature $\left(22^{\circ} \mathrm{C}\right)$ and illumination (14 hours light, 10 hours dark, with lights on at 05:00 hours), and they were allowed free access to Purina rat chow and water. All the procedures involving animals were approved by the Consejo Nacional de Investigaciones Científicas y Técnicas (CONICET) according to the Animal Care and Use Committee Statement of CONICET, 1996. After 20 days of treatment, the animals were killed by cervical dislocation, and freshly dissected uteri from each group were immediately frozen at $-70^{\circ} \mathrm{C}$ until both the messenger RNA (mRNA) and protein determinations.

The content of proteins corresponding to the PPAR $\gamma 1$ and $\gamma 2$ isoforms were evaluated in uterine tissue by Western blot analysis. Each sample was applied to $12 \%$ sodium dodecyl sulfate (SDS)polyacrylamide gel, and separated proteins were transferred onto nitrocellulose membranes. After blocking, the membranes were incubated with rabbit polyclonal antibodies (Santa Cruz Biotechnology, Santa Cruz, CA) against PPAR $\gamma$ using $\beta$-actin (1:500) as an internal control. Rat skeletal muscle extract was used as a positive control for PPAR $\gamma$. Negative controls were performed in the absence of the primary antibody. Individual bands were quantified directly from membranes by densitometry by use of ImageJ software (http://rsbweb.nih.gov/ij/).

We found that both PPAR $\gamma 1$ and $\gamma 2$ isoforms were present in uterine tissue. We also found that neither DHEA nor DHEA $+\mathrm{M}$ treatment modified the expression of PPAR $\gamma$ protein when compared with controls (Table 1). To study whether the gene expression of PPAR $\gamma 1$ and PPAR $\gamma 2$ isoforms was modified by DHEA or DHEA + M treatments, the mRNA contents were measured by reverse-transcriptase polymerase chain reaction (RT-PCR) analysis. Total mRNA from each group of uterine tissue was extracted using TriReagent (Invitrogen, Buenos Aires, Argentina). The products were separated on $2 \%$ agarose and visualized with ethidium bromide staining. The $18 \mathrm{~S}$ protein gene was used as an internal control. The analysis was performed by densitometry scanning by use of an ImageQuant RT ECL (GE Life Sciences, Piscataway, NJ). Bands were compared with internal control by use of ImageJ. For amplification of PPAR $\gamma$ cDNA, the primers were sense $5^{\prime}$-TGA CAC AGA GAT GCC ATT CTG G $3^{\prime}$ and antisense $5^{\prime}$ GAG CTA GAC CCA ATG GTT GCT GAT TAC $3^{\prime}$.

We found that PPAR $\gamma$ mRNA levels were detectable in uterine tissue and that neither DHEA nor DHEA + M treatment modified the expression of PPAR $\gamma$ mRNA when compared with controls (Table 1). In view of these results, we were interested in determining whether hyperandrogenism and the treatment with metformin were able to modulate the expression of 12-LOX and 15-LOX, enzymes responsible for the synthesis of PPAR ligands. The protein content of uterine 12-LOX and 15-LOX were evaluated by Western blot analysis. The protocol was similar to that described previously, with polyclonal antibodies (Santa Cruz Biotechnology) against 12-LOX (1:100) and 15-LOX (1:100).

The DHEA decreased the protein expression of 12-LOX when compared with controls (see Table 1), whereas metformin prevented this effect (see Table 1). We also found that neither DHEA nor DHEA $+\mathrm{M}$ modified the protein expression of 15-LOX when compared with controls (see Table 1). To determine whether the effect of the treatments in the 12-LOX and 15-LOX proteins was a reflection of 12-LOX and 15-LOX gene expression, the mRNA levels corresponding to both enzymes were measured by RT-PCR. Using the same protocol as that

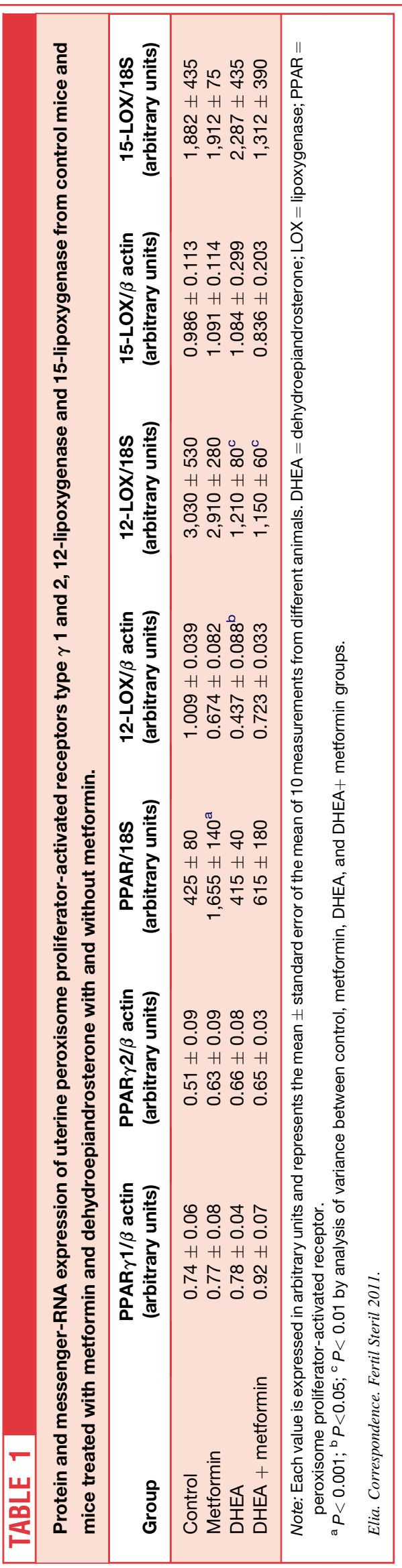


described earlier, for amplification of 12-LOX complementary DNA (cDNA) the primers were sense 5'-TGATCAGGTAGTGAGCACAGGT- $3^{\prime}$ and antisense $5^{\prime}$-CCTTCACATACCTGGCAG TGA-3'. For amplification of $15-\mathrm{LOX}$, the primers were sense 5'-TAGCCATCCAGCTCGAACTG-3 and antisense 5'-GGTGTAGAGTAGGTGAGGAACTA-3'.

Table 1 shows that DHEA decreased the gene expression of 12-LOX when compared with controls and that metformin was not able to prevent this effect. We also found that neither DHEA nor metformin modified the gene expression of 15-LOX (see Table 1 and Supplementary Fig. 1 [available online]).

The detrimental effects of the excess of androgens in the endometrial function contribute to the infertility of women with PCOS (2-4). We had previously reported that the excess of androgens induced the development of uterine structures closely related to the development of precancerous structures $(7,8)$. These adverse effects are mediated by a proinflammatory status characterized by an increased production of prostaglandins by the uterus $(7,8)$. We also found that metformin partially prevented these adverse effects $(7,8)$. These findings, together with the fact that the activation of the PPAR system is related to the uterine function $(26,29)$, the synergistic action of metformin + PPAR treatment described in PCOS $(27,28,30,31)$, and the role of PPAR in regulating the prostaglandin pathway (32), led us to evaluate the action of metformin and the PPAR $\gamma$ system on hyperandrogenized uteri.

We found that both PPAR $\gamma 1$ and $\gamma 2$ are expressed in uterine tissue from prepubertal mice and that neither protein nor gene expression of PPAR $\gamma$ are regulated by the excess of androgen and metformin. The fact that metformin alone increased PPAR $\gamma$ mRNA levels might be due to the fact that metformin is capable of acting in basal conditions even in the absence of stimulus (33). However, experiments are being designed to clarify this point.
Because the expression of PPAR $\gamma$ was not affected by hyperandrogenism, we studied whether hyperandrogenism altered the ligands of PPAR $\gamma$ and consequently the activation of PPAR $\gamma$. Here we demonstrated for the first time that protein and mRNA corresponding to the enzymes 12-LOX and 15-LOX, which are responsible for synthesizing ligands of $\operatorname{PPAR} \gamma(26,34,35)$, are present in uterine tissue from prepubertal mice. In fact, this metabolic pathway of PPAR $\gamma$ activation has been described in other systems, such as monocytes (36), macrophages (34), fibroblasts (35), and uteri (26). However, only the 12-LOX enzyme was susceptible to the adverse action of hyperandrogenism and responded to metformin treatment, thus suggesting that 15-LOX could be a constitutive enzyme in the synthesis of PPAR $\gamma$ ligands. The excess of androgens decreased both the gene and protein expression of 12-LOX, but metformin was able to prevent the decrease in the protein expression, although not the gene expression, of 12-LOX. These findings suggest that metformin might be contributing with a posttranscriptional mechanism in the regulation of 12-LOX expression. However, experiments are being addressed to clarify this point.

The fact that rosiglitazone (synthetic PPAR $\gamma$ ligand) activates the PPAR $\gamma$ system by increasing PPAR $\gamma$ mRNA levels (37) together with data presented here that metformin can modulate the enzyme that synthesizes PPAR $\gamma$ ligand could explain why the combined treatment with glitazones and metformin is more effective in preventing abortions than each separate treatment $(28,30,31)$. It appears that the direct relationship between 12-LOX activity and implantation $(26,38)$ is due to the fact that 12 -LOX regulates the expression of progesterone receptor in uterine tissue during implantation (38). We suggest that hyperandrogenism reduces uterine receptivity, in part, by altering the PPAR $\gamma$ pathway, an alteration that seems to be focused on the enzyme 12-LOX. Metformin is able to prevent the adverse effect of an excess of androgens by modulating the protein expression of 12-LOX.

\section{REFERENCES}

1. Franks S. Polycystic ovary syndrome. N Engl J Med 1995;333:853-61.

2. Okon MA, Laird SM, Tuckerman EM, Li TC. Serum androgen levels in women who have recurrent miscarriages and their correlation with markers of endometrial function. Fertil Steril 1998;69:682-90.

3. Tuckerman EM, Okon MA, Li T, Laird SM. Do androgens have a direct effect on endometrial function? An in vitro study. Fertil Steril 2000;74: 771-9.

4. Sir-Petermann T, Maliqueo M, Angel B, Lara HE, Perez-Bravo F, Recabarren SE. Maternal serum androgens in pregnant women with polycystic ovary syndrome: possible implications in prenatal androgenization. Hum Reprod 2002;17:2573-9.

5. Balen AH, Tan SL, McDougall J, Jacobs HS. Miscarriage rates following in-vitro fertilization are increased in women with polycystic ovary syndrome and reduced by pituitary desensitization with buserelin. Hum Reprod 1993;8:959-64.

6. Pillay OC, Te Fong LF, Crow JC, Benjamin E, Mould $\mathrm{T}$, Atiomo $\mathrm{W}$, et al. The association between polycystic ovaries and endometrial cancer. Hum Reprod 2006;21:924-9.
7. Elia E, Vighi S, Lombardi E, Motta AB. Detrimental effects of hyperandrogenism on uterine functions. Int Immunopharmacol 2008;8:1827-34.

8. Elia EM, Belgorosky D, Faut M, Vighi S, Pustovrh C, Devoto L, et al. The effects of metformin on uterine tissue of hyperandrogenized BALB/c mice. Mol Hum Reprod 2009;15:421-32.

9. Sander V, Solano ME, Elia E, Luchetti CG, Di Girolamo G, Gonzalez C, et al. The influence of dehydroepiandrosterone on early pregnancy in mice. Neuroimmunomodulation 2005;12:285-92.

10. Solano ME, Sander V, Elia E, Luchetti CG, Di Girolamo G, Gonzalez C, et al. Metformin prevents embryonic resorption induced by hyperandrogenization with dehydroepiandrosterone in mice. Reprod Fertil Dev 2006; 18:533-44.

11. Luchetti CG, Mikó E, Szekeres-Bartho J, Paz DA, Motta AB. Dehydroepiandrosterone and metformin modulate progesterone induced blocking factor (PIBF), cyclooxygenase 2 (COX2) and cytokines in early pregnant mice. J Steroid Biochem Mol Biol 2008;111:200-7.

12. Zhou G, Myers R, Li Y, Chen Y, Shen X, FenykMelody $\mathrm{J}$, et al. Role of AMP-activated protein kinase in mechanism of metformin action. J Clin Invest 2001;108:1167-74.
13. Fryer LG, Parbu-Patel A, Carling D. The antidiabetic drugs rosiglitazone and metformin stimulate AMP-activated protein kinase through distinct signaling pathways. J Biol Chem 2002;12: 25226-32.

14. Zou MH, Kirkpatrick SS, Davis BJ, Nelson JS, Wiles WG, Schlattner U, et al. Activation of the AMP-activated protein kinase by the anti-diabetic drug metformin in vivo. J Biol Chem 2004;279: 43940-51.

15. Diamanti-Kandarakis E, Kouli C, Tsianateli T, Bergiele A. Therapeutic effects of metformin on insulin resistance and hyperandrogenism in polycystic ovary syndrome. Eur J Endocrinol 1998;138:269-74.

16. Glueck CJ, Fontaine RN, Wang P, Subbiah MT, Weber K, Illig E, et al. Metformin reduces weight, centripetal obesity, insulin, leptin, and low-density lipoprotein cholesterol in nondiabetic, morbidly obese subjects with body mass index greater than 30. Metabolism 2001;50:856-61.

17. Jakubowicz DJ, Seppälä M, Jakubowicz S, Rodriguez-Armas O, Rivas-Santiago A, Koistinen H, et al. Insulin reduction with metformin increases luteal phase serum glycodelin and insulin-like growth factor-binding protein 1 concentrations 
and enhances uterine vascularity and blood flow in the polycystic ovary syndrome. J Clin Endocrinol Metab 2001;86:1126-33.

18. La Marca A, Morgante G, Palumbo M, Cianci A, Petraglia F, De Leo V. Insulin-lowering treatment reduces aromatase activity in response to folliclestimulating hormone in women with polycystic ovary syndrome. Fertil Steril 2002;78:1234-9.

19. Velázquez E, Acosta A, Mendoza SG. Menstrual cyclicity after metformin therapy in polycystic ovary syndrome. Obstet Gynecol 1997;90:392-5.

20. Glueck CJ, Goldenberg N, Wang P, Loftspring M, Sherman A. Metformin during pregnancy reduces insulin, insulin resistance, insulin secretion, weight, testosterone and development of gestational diabetes: prospective longitudinal assessment of women with polycystic ovary syndrome from preconception throughout pregnancy. Hum Reprod 2004;19:510-21.

21. Issemann I, Green S. Activation of a member of the steroid hormonal receptor superfamily by peroxisome proliferators. Nature 1990;347:645-50.

22. Needleman P, Turk J, Jakschik BA, Morrison AR, Lefkowith JB. Arachidonic acid and metabolism. Annu Rev Biochem 1986;55:69-102.

23. Kuhn H, Borngraber S. Mammalian 15-lipoxygenases: enzyme properties and biological implications. In: Nigam S, Pace-Asciak CR, eds. Lipoxygenases and their metabolites. New York: Plenum, 1999:447:5-28.

24. Brash AR. Lipoxygenases: occurrence, functions, catalysis, and acquisition of substrate. J Biol Chem 1999;274:23679-82.
25. Conrad DJ. The arachidonate 12/15 lipoxygenases: a review of tissue expression and biologic function. Clin Rev Allergy Immunol 1999;17:71-89.

26. Li Q, Cheon YP, Kannan A, Shanker S, Bagchi IC, Bagchi MK. A novel pathway involving progesterone receptor, 12/15-lipoxygenase-derived eicosanoids, and peroxisome proliferator-activated receptor gamma regulates implantation in mice. $\mathrm{J}$ Biol Chem 2004;279:11570-81.

27. Pan QR, Li WH, Wang H, Sun Q, Xiao XH, Brock B, et al. Glucose, metformin, and AICAR regulate the expression of $G$ protein-coupled receptor members in INS-1 beta cell. Horm Metab Res 2009;41:799-804.

28. Prabhakar PK, Doble M. Synergistic effect of phytochemicals in combination with hypoglycemic drugs on glucose uptake in myotubes. Phytomedicine 2009;16:1119-22.

29. Sung B, Park S, Yu BP, Chung HY. Amelioration of age-related inflammation and oxidative stress by PPAR $\gamma$ activator: suppression of NF- $\kappa$ B by 2,4thiazolidinedione. Exp Gerontol 2006;41:590-9.

30. Glueck CJ, Moriera A, Goldenberg N, Sieve L, Wang P. Pioglitazone and metformin in obese women with polycystic ovary syndrome not optimally responsive to metformin. Hum Reprod 2003; 18:1618-25.

31. Legro RS. Pregnancy considerations in women with polycystic ovary syndrome. Clin Obstet Gynecol 2007;50:295-304.

32. Subbaramaiah K, Lin DT, Hart JC, Dannenberg AJ. Peroxisome proliferator-activated receptor gamma ligands suppress the transcriptional activation of cyclooxygenase- 2 : evidence for involvement of activator protein-1 and CREB-binding protein/p300. J Biol Chem 2001;276:12440-8.

33. Sander VA, Facorro GB, Piehl L, Rubín de Celis E, Motta AB. Effect of dehydroepiandrosterone and metformin on corpus luteum in mice. Reproduction 2009;138:571-9.

34. Huang JT, Welch JS, Ricote M, Binder CJ, Willson TM, Kelly C, et al. Interleukin-4dependent production of PPAR- $\gamma$ ligands in macrophages by 12/15-lipoxygenase. Nature 1999;400:378-82.

35. Schild RL, Schaiff WT, Carlson MG, Cronbach EJ, Nelson DM, Sadovsky Y. The activity of PPAR $\gamma$ in primary human trophoblasts is enhanced by oxidized lipids. J Clin Endocrinol Metab 2002;87: 1105-10.

36. Nagy L, Tontonoz P, Alvarez JG, Chen H, Evans RM. Oxidized LDL regulates macrophage gene expression through ligand activation of PPAR $\gamma$. Cell 1998;93:229-40.

37. Chen Q, Sun X, Chen J, Cheng L, Wang J, Wang Y, Sun Z. Direct rosiglitazone action on steroidogenesis and proinflammatory factor production in human granulose-lutein cells. Reprod Biol Endocrinol 2009;7:147-52.

38. Cheon YP, Li Q, Xu X, DeMayo FJ, Bagchi IC, Bagchi MK. A genomic approach to identify novel progesterone receptor regulated pathways in the uterus during implantation. Mol Endocrinol 2002;16:2853-71. 


\section{SUPPLEMENTAL FIGURE 1}

(A) A representative gel corresponding to the protein of peroxisome proliferator-activated receptors type $\gamma$ (PPAR $\gamma 1$ and 2). (B) A representative gel corresponding to the mRNA expression of PPAR $\gamma$. The graphs correspond to the integrated optical density of bands, *** $P<0.001$ by analysis of variance. (C) A representative gel corresponding to the protein of 12 lipoxygenase (12- LOX). (D) A representative gel corresponding to the mRNA expression of 12 lipoxygenase (12- LOX). The graphs correspond to the integrated optical density of bands, ${ }^{\star} P<0.05$ by analysis of variance. (E) A representative gel corresponding to the protein of 15 lipoxygenase (15- LOX). (F) A representative gel corresponding to the mRNA expression of 15 lipoxygenase (15- LOX). The graphs correspond to the integrated optical density of bands, ${ }^{\star \star} P<0.01$ by analysis of variance.
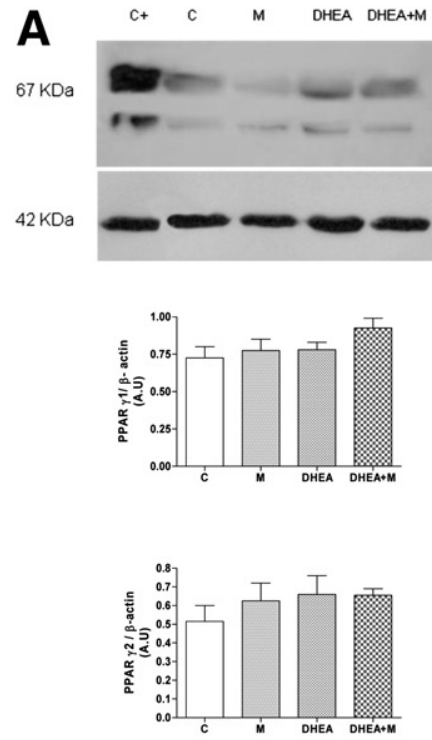

C

$76 \mathrm{KDa}$ $c$ M DHEA $42 \mathrm{KDa}$

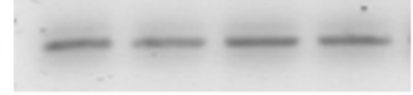

$\leftarrow \beta$-actin

$42 \mathrm{KDa}$

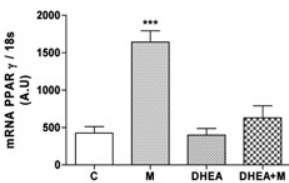

D

\section{$\leftarrow 12$-LOX $\quad 76 \mathrm{KDa}$}

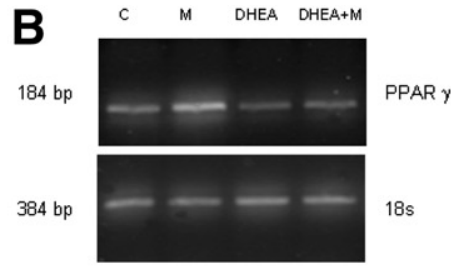

C M

DHEA DHEA+M

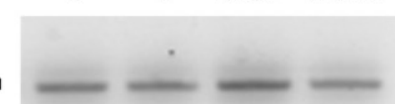

$\leftarrow 15-$ LOX
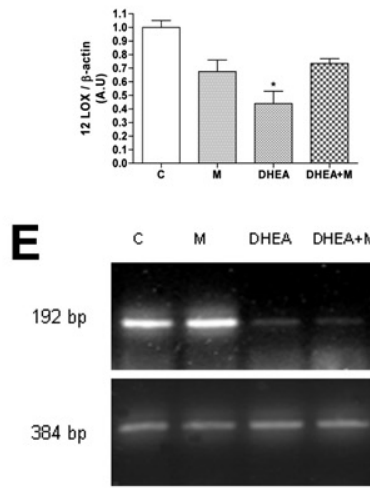

12-LOX

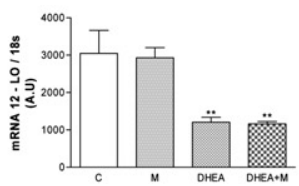

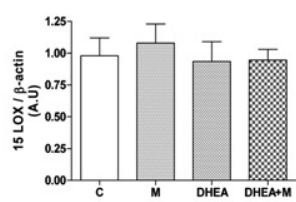

$\mathbf{F}$
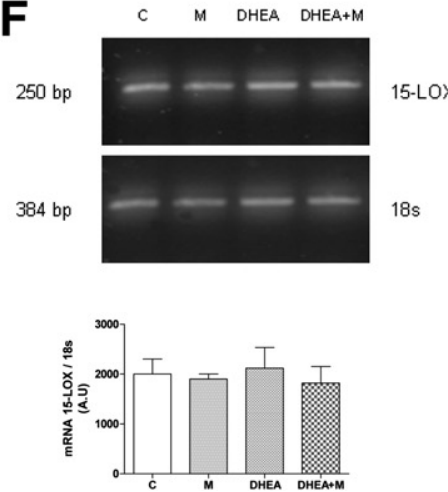